\title{
SETTING EFFICIENCY INDICATORS FOR CENTER PIVOTS ${ }^{1}$
}

\section{RICARDO L. SCHONS ${ }^{2}$, ADROALDO D. ROBAINA ${ }^{3}$, MÁRCIA X. PEITER ${ }^{4}$}

\begin{abstract}
In this study, it was discussed the efficiency criteria in each of the elements that compose a central pivot, and this analysis was applied to two sets of systems located in regions of Cruz Alta and Santo Augusto, state of Rio Grande do Sul, Brazil. The methodology used combines water and energy assessment through an indicator called Normalized Specific Consumption in Irrigation $\left(\mathrm{C}_{\mathrm{ENI}}\right)$, allowing thus a comparison between equipment and projects. The $\mathrm{C}_{\mathrm{ENI}}$ in Cruz Alta region showed $72 \%$ of the equipment above the standard $\left(8.68 \mathrm{kWh} \mathrm{mm}^{-1} \mathrm{ha}^{-1}\right.$ $100 \mathrm{~m}^{-1}$ ), and in Santo Augusto region $64.28 \%$ with consumption above the standard. The mean irrigation efficiency for Cruz Alta region was $29.85 \%$, with standard deviation of $5.41 \%$, and for Santo Augusto region, it was $29.02 \%$, with standard deviation of $5.15 \%$.
\end{abstract}

KEYWORDS: irrigation, consumption, parameter.

\section{AJUSTE DE INDICADORES DE EFICIÊNCIA PARA PIVÔS CENTRAIS}

RESUMO: Neste trabalho, são discutidos critérios de eficiência em cada um dos elementos que compõem um pivô central, sendo esta análise aplicada a dois conjuntos de sistemas localizados, nas regiões de Cruz Alta e Santo Augusto, Rio Grande do Sul. A metodologia utilizada associa as avaliações hídrica e energética por meio de um indicador denominado Consumo Específico Normalizado na Irrigação $\left(\mathrm{C}_{\mathrm{ENI}}\right)$, possibilitando, desta forma, uma comparação entre equipamentos e entre projetos. $\mathrm{O} \mathrm{C}_{\mathrm{ENI}}$ na região de Cruz Alta apresentou $72 \%$ dos equipamentos acima do padrão $\left(8,68 \mathrm{kWh} \mathrm{mm}^{-1} \mathrm{ha}^{-1} 100 \mathrm{~m}^{-1}\right)$, e na região de Santo Augusto, 64,28\% com o consumo acima do padrão. A eficiência de irrigação média para a região de Cruz Alta foi de 29,85\%, com desviopadrão de 5,41\%; e para a Região de Santo Augusto foi de 29,02\%, com desvio padrão de 5,15\%.

PALAVRAS-CHAVE: irrigação, consumo, parâmetros.

\section{INTRODUCTION}

Deficiencies in irrigation projects are virtually found in all regions, usually with ignorance of those who use them for production. These deficiencies may also include installation and maintenance to the equipment, making the use efficient of the equipment has a value lower than expected or what is possible, depending on their characteristics.

BARRETO et al. (2004) state that the implementation of modern irrigation systems, by itself, does not guarantee high overall efficiency of water use in agroecosystems. Projects are designed according to the uniformity expected for a given situation. The higher the expected efficiency, the greater the investment required in equipment, care and maintenance to the operation.

There is no support to consumers of irrigation systems so they may, at the acquisition, also compare the equipment in his character of energy efficiency. Many designers make use of this deficiency in the market for producers to take an initial investment projects more economic but less efficient in its service life. In some design situations, throughout service the life of the equipment, new technologies arise that make it more viable and attractive, being necessary, therefore, constant evaluation and updating of installed systems.

\footnotetext{
${ }^{1}$ Extraído da Tese de Doutorado do primeiro autor, com bolsa de estudos concedida pelo CNPq.

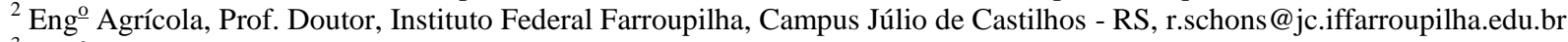

${ }^{3}$ Eng ${ }^{-}$Agrônomo, Prof. Doutor, Centro de Ciências Rurais, UFSM, Santa Maria - RS.

${ }^{4}$ Eng $^{\mathrm{a}}$ Agrônoma, Profa. Doutora, Centro de Ciências Rurais, UFSM, Santa Maria - RS.

Recebido pelo Conselho Editorial em: 12-5-2010
}

Aprovado pelo Conselho Editorial em: 28-12-2011 
GILLEY et al. (1990) claim that the reduction of operating pressure for the use of low pressure transmitters is the easiest way to reduce the power consumption of irrigation center pivot, whereas LIMA (2008) notes that we should detail the system irrigation and analyze the influence of each of the elements of the irrigation system in the composition of overall yield. We should also relate the energy consumed to the useful volume of water, i.e., available in the plant root zone.

Considering the difficulty to comparison of the various irrigation systems because of different possibilities of installation, cost and time variation in operating conditions, it is important to define an efficiency index. Thus, it is justified to study and quantify the technical parameters that may be considered in the characterization of energy equipment, to form this index.

In this study, it was applied the criteria of efficiency in each of the elements, pump set, suction piping, downstream, equipment air tubing, and sprinkler system, which comprises a central pivot, and these elements justified the changes to be considered in the project, thus discussing the criteria to be analyzed in the equipment efficiency. This analysis was applied to two sets of irrigation systems by central pivot, located in the state of Rio Grande do Sul.

\section{MATERIAL AND METHODS}

In order to enhance efficiency indicators for irrigation projects with a central pivot, the methodology and study of indicators used was proposed by LIMA (2008).

According to the method, the efficiency of irrigation should be composed of agricultural indicators, the uniformity coefficient, and energy indicators. The proposal increases the specific consumption calculation in each of the components of the irrigation system.

For the energy evaluation of equipment, 39 equipments were selected in the state of Rio Grande do Sul, with 25 equipments in Cruz Alta region and 14 in Santo Augusto region.

The irrigation system was divided into its main parts and it was calculated the power consumed in each, as well as their efficiency.

\section{Power dissipated in the engine and pump}

The engine efficiency was calculated by the index curve of the engine load provided by the manufacturer, that in the utilization of catalogs of the engine, three points, 50, 75, and 100\% load, are extracted, the yield is related to engine load. Found engine efficiency, it is possible to obtain the power supplied on the shaft.

Considering the income unit in direct couplings between engines and pumps, and considering that the pump efficiency depends on its operating point, the pump hydraulic power is the study the pump does to raise a flow of water at a certain manometric height, according to eq.(1):

$$
\mathrm{P}_{\mathrm{H}}=\gamma \mathrm{Q}_{\mathrm{s}} \mathrm{H}_{\mathrm{m}}
$$

In which,

$\mathrm{P}_{\mathrm{H}}$ - hydraulic power, $\mathrm{kW}$;

$\gamma$ - density of water, $\mathrm{kN} \mathrm{m}^{-3}$;

$\mathrm{Q}_{\mathrm{S}}$ - flow pumped in the system, $\mathrm{m}^{3} \mathrm{~s}^{-1}$, and

$\mathrm{H}_{\mathrm{m}}$ - manometric height supplied by the pump, $\mathrm{m}$.

For this study, it was performed a study of the efficiency of each pump by the manufacturer's catalog, and the flow rate used was estimated by the test of uniformity of the equipment described by ABNT NBR 1244 (1998), and the pressure was taken by the reading of the manometer on the pump at the time of test, where the electrical power consumed by the pump may be calculated from eq.(2): 


$$
\mathrm{P}_{\mathrm{Ed}}=\frac{\mathrm{P}_{\mathrm{H}}}{\eta_{\mathrm{b}}}
$$

In which,

$\mathrm{P}_{\mathrm{Ed}}$ - electrical power dissipated in the element, $\mathrm{kW}$, and

$\eta_{\mathrm{b}}$ - pump efficiency, decimal.

The energy efficiency indicator of the engine and pump, proposed in IWA (2000), allows determining the power per cubic meter to raise a manometric height of $100 \mathrm{~m}$, as shown in eq.(3):

$$
\mathrm{C}_{\mathrm{EN}}=\frac{\mathrm{P}_{\text {entrance }}}{\mathrm{Q}_{\mathrm{S}} \mathrm{H}_{\mathrm{m}}} 100
$$

In which,

$\mathrm{C}_{\mathrm{EN}}$ - normalized energy consumption, $\mathrm{kW} \mathrm{h} \mathrm{m} \mathrm{m}^{-3} 100 \mathrm{~m}^{-1}$;

$\mathrm{P}_{\text {entrance }}$ - electric power measured in the engine, $\mathrm{kW}$, and

$\mathrm{Q}_{\mathrm{S}}$ - flow pumped in the system, $\mathrm{m}^{3} \mathrm{~h}^{-1}$.

\section{Power loss in the suction and adduction piping}

The power dissipated in the suction and adduction piping, considering the points determined by the manometer, may be obtained by eq.(4). The electrical power associated with losses in the suction, adduction or lateral line is described in eq.(5):

$$
\begin{aligned}
& \mathrm{P}_{\mathrm{d}}=\gamma \mathrm{Q}_{\mathrm{S}} \Delta \mathrm{h} \\
& \mathrm{P}_{\mathrm{Ed}}=\frac{\mathrm{P}_{\mathrm{d}}}{\eta_{\mathrm{m}} \eta_{\mathrm{b}}}
\end{aligned}
$$

In which,

$\mathrm{P}_{\mathrm{d}}$ - power dissipated in the element, $\mathrm{kW}$;

$\Delta \mathrm{h}$ - loss of pressure in the element, $\mathrm{m}$.

$\mathrm{P}_{\mathrm{Ed}}$ - electrical power dissipated in the element, $\mathrm{kW}$, and

$\eta_{\mathrm{m}}$ - engine efficiency, decimal.

The energy efficiency indicator associated with the adduction and the suction piping is composed of the pressure drop in $100 \mathrm{~m}$, calculated by eq.(6). The loss of pressure in $100 \mathrm{~m}$ will be considered the loss distributed along the piping and localized loss, because it is the necessary condition for comparison with values obtained during testing.

The energy efficiency indicator proposed for piping determines the power per cubic meter to move fluid in a kilometer of piping, as shown in eq.(7):

$$
\begin{aligned}
\Delta \mathrm{h}_{100} & =\frac{\Delta \mathrm{h}_{1-2}}{1} 100 \\
\mathrm{C}_{\mathrm{ENT}} & =\frac{\mathrm{P}_{\mathrm{d}}}{3,61 \mathrm{Q}_{\mathrm{S}}}
\end{aligned}
$$

In which,

$\Delta \mathrm{h}_{100}$ - loss of load in $100 \mathrm{~m}$, mca $100 \mathrm{~m}^{-1}$;

$\Delta \mathrm{h}_{1-2}$ - loss of load between points 1 and 2, mca;

1 - length of piping, $\mathrm{m}$;

$\mathrm{C}_{\mathrm{ENT}}$ - Normalized Specific Consumption in Piping, $\mathrm{kW} \mathrm{h} \mathrm{m}^{-3} \mathrm{~km}^{-1}$, and

$\mathrm{Q}_{\mathrm{S}}$ - flow pumped in the system, $\mathrm{m}^{3} \mathrm{~s}^{-1}$.

To estimate the power losses due to the adopted choice of the diameter of the adduction, it was calculated a reference diameter using the Bresse Equation, with a coefficient "K" of 0.8 , presented by COLOMBO (2003) for a flow rate of $2.0 \mathrm{~m} \mathrm{~s}^{-1}$. 


\section{Power dissipated in the lateral line}

The energy dissipated along the lateral line is obtained similarly to the suction and adduction piping. However, due to the output of a given flow rate in each sprinkle, and also due to the change in diameter that occurs along the pipe, adjustments must be made.

The pressure loss in the lateral line pipe may be calculated considering the segments between each water outlet on the piping, where it remains constant flow rate and piping diameter, using the equation of loss of universal load.

\section{Power dissipated in sprinkler}

The efficiency of application relates to useful flow to crops with the total flow pumped through the system. Thus, it is possible to determine the Power Dissipation by Sprinklers (eq.8)) and Specific Consumption in Sprinklers (eq.(9):.

$$
\begin{aligned}
& \mathrm{P}_{\text {Dasp }}=\gamma \mathrm{Q}_{\mathrm{S}}\left[\mathrm{H}_{\mathrm{m}}\left(1-\frac{\mathrm{EA}_{80}}{100}\right)+\frac{\mathrm{EA}_{80}}{100} \mathrm{~h}_{\text {asp }}\right] \\
& \mathrm{C}_{\text {Easp }}=\frac{\mathrm{P}_{\text {Dasp }}}{\mathrm{Q}_{\mathrm{S}} \mathrm{EA}_{80} 3.6}
\end{aligned}
$$

In which,

$\mathrm{P}_{\text {Dasp }}$ - power dissipated in the sprinklers, $\mathrm{kW}$;

$\mathrm{Hm}$ - manometric height supplied by the pump, m;

$\mathrm{EA}_{80}$ - application efficiency for $80 \%$ of the appropriately irrigated area, decimal;

$\mathrm{h}_{\mathrm{asp}}$ - sprinkler manometric height, $\mathrm{m}$, and

$\mathrm{C}_{\text {Easp }}$ - specific consumption in sprinklers, $\mathrm{kWh} \mathrm{mm}^{-1} \mathrm{ha}^{-1}$.

\section{System efficiency}

The useful hydraulic power of the irrigation system is used, calculated by the useful flow and the pumping geometry gap (eq.(10)). A full evaluation of the system relates the Normalized Specific Consumption in Irrigation and Irrigation Efficiency according to eqs.(11-13).

$$
\begin{aligned}
& \mathrm{P}_{\mathrm{U}}=\gamma \mathrm{Q}_{\mathrm{S}} \frac{\mathrm{EA}_{80}}{100} \mathrm{~h}_{\mathrm{g}} \\
& \mathrm{C}_{\mathrm{ENI}}=\frac{\mathrm{P}_{\text {entrance }} 100}{\mathrm{Q}_{\mathrm{S}} \mathrm{EA}_{80} \mathrm{~h}_{\mathrm{g}} 3.6} \\
& \mathrm{E}_{\mathrm{I}}=\frac{\mathrm{P}_{\mathrm{U}}}{\mathrm{P}_{\text {entrance }}} 100 \\
& \mathrm{E}_{\mathrm{I}}=\mathrm{EA}_{80} \frac{\mathrm{h}_{\mathrm{g}}}{\mathrm{H}_{\mathrm{m}}} \eta_{\mathrm{b}} \eta_{\mathrm{m}}
\end{aligned}
$$

In which,

$\mathrm{P}_{\mathrm{U}}$ - useful power of the irrigation system, $\mathrm{kW}$;

$\mathrm{h}_{\mathrm{g}}$ - downstream geometric height, $\mathrm{m}$;

$\mathrm{Q}_{\mathrm{S}} \frac{\mathrm{EA}_{80}}{100}$ - useful flow of the irrigation system, $\mathrm{m}^{3} \mathrm{~s}^{-1}$;

$\mathrm{C}_{\mathrm{E}}$ - specific consumption, $\mathrm{kWh} \mathrm{m}^{-3}$;

$\mathrm{C}_{\mathrm{ENI}}$ - Normalized Specific Consumption in Irrigation, $\mathrm{kWh} \mathrm{mm}^{-1} \mathrm{ha}^{-1} 100 \mathrm{~m}^{-1}$, and

$\mathrm{E}_{\mathrm{I}}$ - irrigation efficiency, $\%$. 
The income or Irrigation Efficiency, determined by the ratio of useful hydraulic power to irrigation and electrical power input, determines the percentage of energy that is used in the irrigation system.

\section{RESULTS AND DISCUSSION}

\section{Engine and pump set}

In the evaluation of an irrigation system, the efficiency of the engine and pump set are important due to the representation of the energy dissipated in this element.

The Cruz Alta region has an mean yield measured at the pump of $74.03 \%$, with a standard deviation of $5.26 \%$; the Santo Augusto region has $76.60 \%$ yield measured at the pump, with a standard deviation of $3.37 \%$. It can be seen that the yields are near $75 \%$, and, according to MACINTYRE (1982), the yield which may be considered acceptable is $75 \%$ for medium-sized pumps, below this value is considered a low yield.

In the Cruz Alta region, it was found $24 \%$ of the equipment with less than $5 \%$ discrepancy between the possible maximum efficiency for the pump, calculated from the specific speed, flow and pressure; $56 \%$ are between 5 and $10 \%$, and $20 \%$ of the equipment have a discrepancy greater than 10\%; in Santo Augusto region, 28\% of the equipment are up to 5\% discrepancy, 64\% of the equipment are between 5 and 10\%, and 7\% is more than 10\%. MARCOLIN \& ROBAINA (2002), in the analysis of pumping for rice, also found discrepancies, and they show that the resizing of the pumps may bring considerable savings in energy consumption.

\section{Adduction and suction piping}

There is a variation of up to $1016.31 \%$ in the Cruz Alta region, and $619.89 \%$ in Santo Augusto region, between the calculated and measured values for the load loss in the adduction piping. For the analysis of these data, it is important to determine three factors that influence variation: roughness, special parts and problems with gaps.

The load loss in $100 \mathrm{~m}$, an indicator commonly used by designers, ranged in the adduction pipes tested between 0.17 and $5.92 \mathrm{~m}$, which provides a loss of power of $1.08 \mathrm{~kW}$ and $68.15 \mathrm{~kW}$ in Cruz Alta Region, and between 0.95 and $9.01 \mathrm{~m}$ that provided loss of power of $46.32 \mathrm{~kW}$ and $11.85 \mathrm{~kW}$ in Santo Augusto region. It is observed that it may be not take as a single parameter the load loss in $100 \mathrm{~m}$ of adduction, thus justifying the use of the indicator in the Normalized Specific Consumption in Piping which, in Cruz Alta region, ranged from $0.01 \mathrm{kWh} \mathrm{m}^{-3} \mathrm{~km}^{-1}$ to $0.22 \mathrm{kWh} \mathrm{m}^{-3} \mathrm{~km}^{-1}$, and in Santo Augusto region ranged from $0.03 \mathrm{kWh} \mathrm{m}^{-3} \mathrm{~km}^{-1}$ to $0.23 \mathrm{kWh} \mathrm{m}^{-3} \mathrm{~km}^{-1}$. In Cruz Alta region, in the data in the study, the adduction pipe with greater consumption consumes 22 times more specific energy than the adduction pipe with less consumption; and in Santo Augusto region the adduction pipe with higher consumption consumes 7.6 times more specific energy than the adduction pipe with less consumption, which is a parameter that has a higher degree of equivalence on the results comparison.

\section{Lateral line}

The most critical situation, in Cruz Alta region, refers to the equipment with normalized specific consumption of $0.48 \mathrm{kWh} \mathrm{m}^{-3} \mathrm{~km}^{-1}$ and, in Santo Augusto region, the equipment with normalized specific consumption of $0.50 \mathrm{kWh} \mathrm{m}^{-3} \mathrm{~km}^{-1}$. The Load Loss in $100 \mathrm{~m}$ found is equal to $9.90 \mathrm{~m}$ in Cruz Alta region and $12.5 \mathrm{~m}$ in Santo Augusto region.

The variance between tested and calculated loss of load is justified because of the design problems found in equipment, sprinkler system problems, and problems related to lack of maintenance, supporting the argument made by GUERRA (2004), where he mentions that the irrigation equipment are used for several years without proper maintenance, especially in items of sprinkler system. 


\section{Sprinkler system}

Considering the flow pumped, the blade collected from the assessment of a pivot and an area appropriately irrigated equal to $80 \%$, it is possible to determine the power consumption and the specific consumption in sprinklers (CEasp).

It is observed in Cruz Alta region a range of consumption, ranging from $0.86 \mathrm{kWh} \mathrm{mm}^{-1} \mathrm{ha}^{-1}$ to $1.90 \mathrm{kWh} \mathrm{mm}^{-1} \mathrm{ha}^{-1}$, to ensure a millimeter of water depth in at least $80 \%$ of a hectare. The powers for the same equipment, $31.49 \mathrm{~kW}$ to $38.98 \mathrm{~kW}$.

The variation in energy consumed by the sprinklers in the tested equipment is a consequence of the Application Efficiency of each system, here considered the application for at least $80 \%$ of the irrigated area, thus assuming the value of the CUC as Application Efficiency. SILVA et al. (1997) argue that it is often necessary to evaluate the efficiency of an irrigation system in order to determine its applicability in certain conditions.

\section{Efficiency indicators of irrigation system}

After examined the elements, it was possible to calculate three indicators of energy efficiency for the complete irrigation system. This is the Specific Consumption (CE), usually used by professionals, the Normalized Specific Consumption in Irrigation $\left(\mathrm{C}_{\mathrm{ENI}}\right)$, as shown in Figure 1, and Irrigation Efficiency $\left(\mathrm{E}_{\mathrm{I}}\right)$.

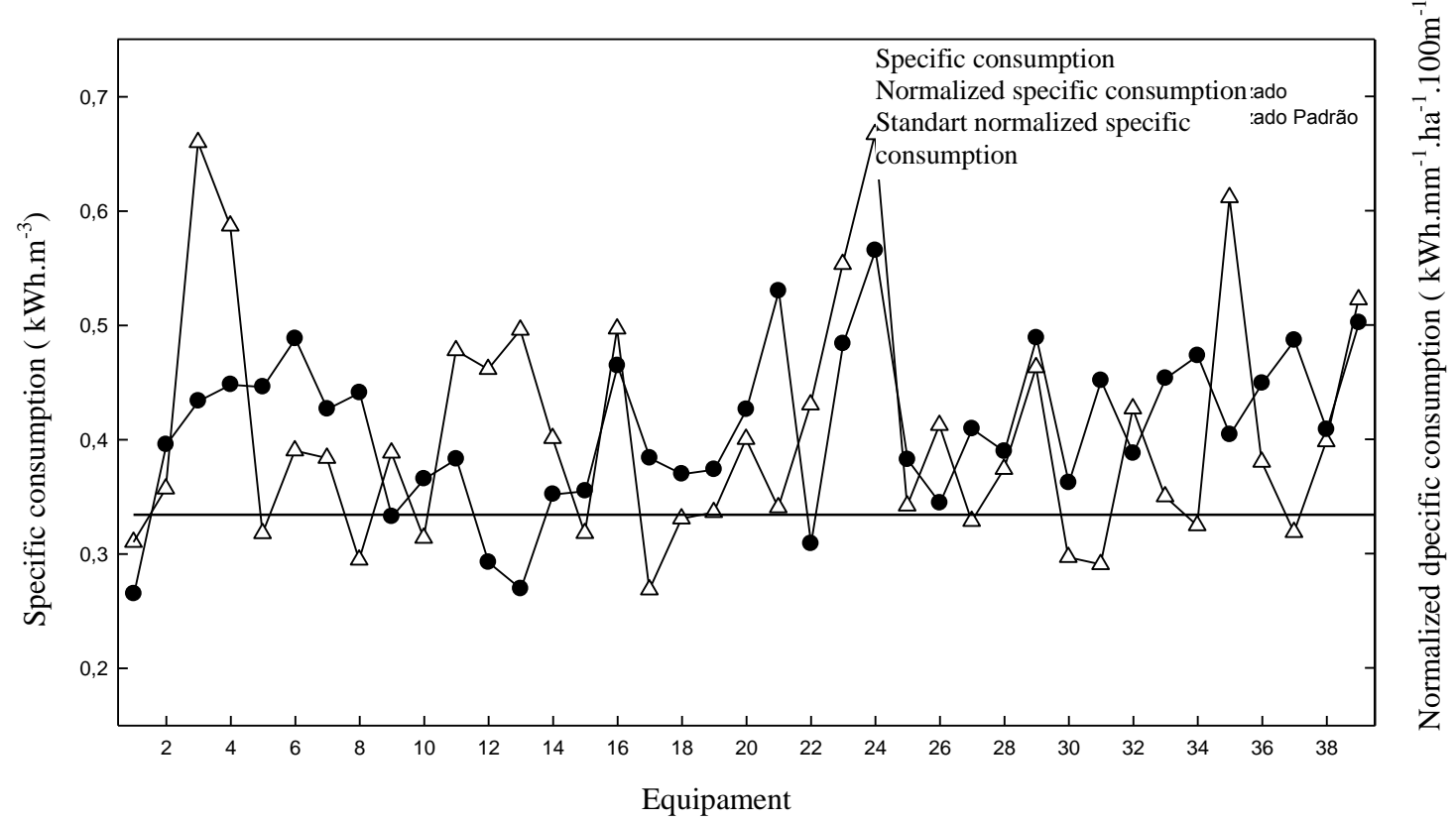

FIGURE 1. Normalized specific consumption, specific consumption of irrigation equipment in the two regions studied, and standard normalized specific consumption. Cruz Alta (equipment 1 to 25) and Santo Augusto (equipment 26 to 39).

The Specific Consumption may directly provide the energy per volume of water pumped. It is, then, an indicator dependent on local topography, however, important to compare different projects within the same irrigation system and to monitor the depreciation of equipment efficiency; represented by the study of PINTO et al. (2006) in western Bahia, showing equipments with efficiencies below $80 \%$.

It is observed that, despite the Equipment 29 pump set provide the third worst yield $(66.46 \%)$ and specific consumption $\left(0.41 \mathrm{~kW} \mathrm{~h} \mathrm{~m}^{-3}\right)$, in general assessment, using the Normalized Specific Consumption, the equipment presents a value slightly higher than the mean, which is $10.11 \mathrm{~kW} \mathrm{~h} \mathrm{~mm}^{-1} \mathrm{ha}^{-1} 100 \mathrm{~m}^{-1}$. 
The mean Normalized Specific Consumption for Cruz Alta region was $9.99 \mathrm{~kW} \mathrm{~h} \mathrm{~mm}^{-1} \mathrm{ha}^{-1}$ $100 \mathrm{~m}^{-1}$, with a standard deviation of $2.05 \mathrm{~kW} \mathrm{~h} \mathrm{~mm}^{-1} \mathrm{ha}^{-1} 100 \mathrm{~m}^{-1}$; and for Santo Augusto region, it was $10.24 \mathrm{~kW} \mathrm{~h} \mathrm{~mm}^{-1} \mathrm{ha}^{-1} 100 \mathrm{~m}^{-1}$, with standard deviation of $2.14 \mathrm{~kW} \mathrm{~h} \mathrm{~mm}^{-1} \mathrm{ha}^{-1} 100 \mathrm{~m}^{-1}$.

When the values found in the two regions are compared with $\mathrm{C}_{\mathrm{ENI}}$ proposed as standard by LIMA (2008), $72 \%$ of the equipment in Cruz Alta region is above the standard $\left(8.68 \mathrm{kWh} \mathrm{mm}^{-1} \mathrm{ha}^{-1}\right.$ $100 \mathrm{~m}^{-1}$ ), and in Santo Augusto region $64.28 \%$ are with consumption above the standard. These results do not contest the default value assumed, but it is interesting to show how to use this indicator and make inferences with it in the condition of the equipment studied.

The mean Irrigation Efficiency for Cruz Alta region was 29.85\%, with a standard deviation of $5.41 \%$; and for Santo Augusto region was $29.02 \%$, with a standard deviation of $5.15 \%$, high levels when compared with the evaluation performed by LIMA et al. (2006) in an irrigation system where the energy efficiency index is $14.63 \%$, and, after the proposed modification, the index increase is at $34.96 \%$, and they may also be higher.

\section{CONCLUSIONS}

In Cruz Alta region, $72 \%$ of the equipment present the $\mathrm{C}_{\mathrm{ENI}}$ above the standard $\left(8.68 \mathrm{kWh} \mathrm{mm}^{-1} \mathrm{ha}^{-1} 100 \mathrm{~m}^{-1}\right)$, and Santo Augusto region, $64.28 \%$ are above standard.

Mean Irrigation Efficiency $\left(\mathrm{E}_{\mathrm{I}}\right)$ for Cruz Alta region was $29.85 \%$, with a standard deviation of $5.41 \%$, and for Santo Augusto region, it was $29.02 \%$, with a standard deviation of $5.15 \%$.

The assessment procedures currently used, evaluating water and energy separately, bring important contributions, but by the methodology used, the combination of these parameters in the indicator of Normalized Specific Consumption in Irrigation $\left(\mathrm{C}_{\mathrm{ENI}}\right)$ enables comparison between equipments and between projects, an aspect extremely important. This should be further studied for its consolidation as a parameter.

\section{REFERENCES}

ABNT. ASSOCIAÇÃO BRASILEIRA DE NORMAS TÉCNICAS. NBR 14244: Equipamentos de irrigação mecanizada - Pivô central e lateral móvel providos de emissores fixos ou rotativos Determinação da uniformidade de distribuição de água. São Paulo, 1998.

BARRETO, A.N.; SILVA, A.A.G.; BOLFE, E.L. Irrigação e drenagem na empresa agrícola: impacto ambiental versus sustentabilidade. Aracajú: Embrapa Tabuleiros Costeiros; Campina Grande: Embrapa Algodão, 2004. 418 p.

COLOMBO, A. Pivô central. In: MIRANDA, J.H.; PIRES, R.C.M. Irrigação. Jaboticabal: Associação Brasileira de Engenharia Agrícola, 2003. v.2., p.209-258. (Série Engenharia Agrícola).

GILLEY, J.R.; HACKBART, C.A.; STETSON, L.E.; FEYEN, J. Energy management. In: HOFFMAN, G.J.; HOWEL, T.A.; SOLOMON, K.N. (Ed.). Management of farm irrigation systems. St. Joseph: ASAE,1990. p.719-746.

GUERRA, A.F. Adequação e manejo das irrigações por aspersão por pivô central no cerrado. 2004. Disponível em: <http//www.agronline.com.br/ artigos/artigo.php?id=141>. Acesso em: 14 maio 2010.

IWA. INTERNATIONAL WATER ASSOCIATION. Performance indicators for water supply services. Laboratório Nacional de Engenharia Civil, Lisboa, 2000. 200 p.

LIMA, A.C. de. Desenvolvimento de indicadores de eficiência energética para avaliação de pivôs centrais de irrigação. 2008. 194 f. Tese (Doutorado em Engenharia Elétrica) - Universidade Federal de Uberlândia, Uberlândia, 2008. 
LIMA, A.C.; GUIMARÃES JÚNIOR, S.C.; CAMACHO, J.R.; SALERNO, C.H. Desenvolvimento de uma metodologia para a avaliação da eficiência energética de pivôs centrais de irrigação. In: ENCONTRO DE ENERGIA NO MEIO RURAL, 6., 2006, Campinas. Anais...

MACINTYRE, A.J. Bombas e instalações de bombeamento. Rio de Janeiro: Guanabara Dois, 1982. $667 \mathrm{p}$.

MARCOLIN, E.; ROBAINA, A.D. Consumo de energia e eficiência das estações de bombeamento de lavouras de arroz irrigado. Ciência Rural, Santa Maria, v.32, n.2, p.229-235, 2002.

PINTO, J.M.; SILVA, C.; OLIVEIRA, C.A.S. Influência de variáveis climáticas e hidráulicas no desempenho da irrigação de um pivô central no oeste baiano. Engenharia Agrícola, Jaboticabal, v.26, n.1, p.76-85, 2006.

SILVA, D.D.; RAMOS, M.M.; MARTINEZ, M.A.; DENÍCULI, W. Uniformidade de distribuição de água em sistemas de aspersão, com utilização de aspersor fixo com placa defletora auxiliar. Engenharia Agrícola, Jaboticabal, v.17, n.4, p.281-292, 1997. 